\title{
Genetic variant of V825I in the ATP-binding cassette transporter A1 gene and serum lipid levels in the Guangxi Bai Ku Yao and Han populations
}

Xiao-Li Cao ${ }^{1,2}$, Rui-Xing Yin ${ }^{1 *}$, Dong-Feng Wư ${ }^{1}$, Lin Miao ${ }^{1}$, Lynn Htet Htet Aung ${ }^{1}$, Xi-Jiang Hư ${ }^{1}$, Qing Li', Ting-Ting Yan", Wei-Xiong Lin ${ }^{3}$, Shang-Ling Pan ${ }^{4}$

\begin{abstract}
Background: Several genetic variants in the ATP-binding cassette transporter A1 (ABCA1) gene have associated with modifications of serum high-density lipoprotein cholesterol (HDL-C) levels and the susceptibility for coronary heart disease, but the findings are still controversial in diverse racial/ethnic groups. Bai Ku Yao is an isolated subgroup of the Yao minority in southern China. The present study was undertaken to detect the possible association of V825I (rs2066715) polymorphism in the ABCA1 gene and several environmental factors with serum lipid levels in the Guangxi Bai Ku Yao and Han populations.
\end{abstract}

Methods: A total of 677 subjects of Bai Ku Yao and 646 participants of Han Chinese were randomly selected from our previous stratified randomized cluster samples. Polymerase chain reaction and restriction fragment length polymorphism assay combined with gel electrophoresis were performed for the genotyping of V825I variant, and then confirmed by direct sequencing.

Results: The levels of serum total cholesterol (TC), HDL-C, apolipoprotein (Apo) Al and ApoB were lower in Bai Ku Yao than in $\operatorname{Han}(P<0.01$ for all). The frequency of $G$ and $A$ alleles was $57.4 \%$ and $42.6 \%$ in Bai Ku Yao, and $57.7 \%$ and $42.3 \%$ in $\operatorname{Han}(P>0.05)$; respectively. The frequency of GG, GA and AA genotypes was $33.7 \%, 47.4 \%$ and $18.9 \%$ in Bai Ku Yao, and 33.4\%, 48.6\% and 18.0\% in Han ( $P>0.05$ ); respectively. There was no difference in the genotypic and allelic frequencies between males and females in the both ethnic groups. The subjects with AA genotype in Bai Ku Yao had higher serum TC levels than the subjects with GG and GA genotypes $(P<0.05)$. The participants with AA genotype in Han had lower serum HDL-C and ApoAl levels than the participants with GG and GA genotypes $(P<0.05$ for each), but these results were found in males but not in females. Multivariate linear regression analysis showed that the levels of TC in Bai Ku Yao and HDL-C and ApoAl in male Han were correlated with genotypes $(P<0.05$ for all). Serum lipid parameters were also correlated with sex, age, body mass index, alcohol consumption, and blood pressure in both ethnic groups $(P<0.05-0.001)$.

Conclusion: The present study suggests that the V825I polymorphism in the ABCA1 gene is associated with male serum HDL-C and ApoAl levels in the Han, and serum TC levels in the Bai Ku Yao populations. The difference in the association of V825I polymorphism and serum lipid levels between the two ethnic groups might partly result from different ABCA1 gene-enviromental interactions.

\footnotetext{
* Correspondence: yinruixing@yahoo.com.cn

'Department of Cardiology, Institute of Cardiovascular Diseases, the First Affiliated Hospital, Guangxi Medical University, 22 Shuangyong Road,

Nanning 530021, Guangxi, People's Republic of China

Full list of author information is available at the end of the article
} 


\section{Introduction}

Human and animal model studies have confirmed that abnormal lipid metabolism leads to kinds of diseases, especially altered lipoprotein levels are crucial risk factors for atherosclerosis [1]. A number of studies have established that elevated concentrations of plasma highdensity lipoprotein cholesterol (HDL-C) and lower lowdensity lipoprotein cholesterol (LDL-C) levels reduce the risk for coronary heart disease (CHD) [2-5], but the causality of this inverse association is still incompletely known. There are multiple mechanisms by which HDL$\mathrm{C}$ can be cardioprotective and LDL-C inducing atherogenesis. A widely accepted view is that HDL-C is atheroprotective because of its role in reverse cholesterol transport, a metabolic pathway whereby excess cholesterol in peripheral tissues is transported to the liver for preventing detrimentally accumulation in body [6,7]. It is estimated that up to $60 \%$ of the interindividual variation in plasma HDL-C and LDL-C levels is due to genetic variation [8-11], and that the major portion of this variation is polygenic attributable to sequence variation in various loci. It would be interesting to assess the possible association between particular gene variants and serum lipid profiles in the general population.

The ATP-binding cassette transporter A1 (ABCA1) is a member of the large ATP binding cassette transporters family, which comprises proteins translocating a wide variety of substrates across cell membranes utilising ATP [12]. It has been suggested that ABCA1 participates in the efflux of free cholesterol from peripheral cells, including macrophage-derived foam cells, and contributes to the formation of mature HDL by facilitating the lipidation of circulating nascent apolipoprotein (Apo) AI particles with free cholesterol at the plasma membrane [13-15]. Loss-of-function mutations in the ABCA1 gene cause Tangier disease, a rare genetic disorder characterized by near absence of HDL and accumulation of lipids within cells in various tissues including the blood vessel wall [16-19]. ABCA1 mutation carriers have markedly higher incidence of CHD compared with non-carriers [20]. In addition, in families of Tangier disease patients, onset of CHD is significantly earlier in mutation carriers than in noncarriers [21,22]. These results suggest that functional deficiency of $A B C A 1$ could also induce an atherogenic decrease in HDL-C levels, incriminating the ABCA1 gene as a candidate for atherosclerotic complications in the general population [23-25]. A number of single nucleotide polymorphisms (SNPs) have been identified both in the coding and promoter regions of the ABCA1 gene http://www.ncbi.nlm. nih.gov/SNP/. However, for most of them there are no robust data about their functional relevance. A common variant of V825I in the ABCA1 gene is a missense SNP in the exon 17 that locates in the middle part of the protein corresponding to sixth transmembrane $\alpha$-helix with mutation of GTC $\rightarrow$ ATC. The ABCA1 V825I polymorphism has been found to be associated with modifications of serum HDL-C levels in some studies [26-29] but not in others [30-33]. Thus, it would be interesting to evaluate whether common genetic variations in the gene constitute a major source of interindividual variability in serum lipid levels and CHD susceptibility in the different ethinc populations.

Han is the largest ethnic group and Yao is the eleventh largest minority among the 55 minority groups in China according to the population size. Bai Ku Yao (White-trouser Yao, all of men wear white knee-length knickerbockers) is an isolated branch of the Yao minority with the population size about 30000 . Because of isolation from the other ethnic groups, the special customs and cultures including their clothing, intra-ethnic marriages, dietary habits, and life style are still completely preserved to the present day. In several previous epidemiological studies, we showed that several serum lipid parameters were lower in Bai Ku Yao than in Han Chinese from the same region $[34,35]$. This ethnic difference in serum lipid profiles remains unknown. We hypothesized that some genetic factors may be different between the two ethnic groups. Therefore, the aim of the present study was to detect the association of V825I polymorphism in the ABCA1 gene and several environmental factors with serum lipid phenotypes in the Guangxi Bai Ku Yao and Han populations.

\section{Materials and methods Study population}

A total of 677 participants of Bai Ku Yao and 646 subjects of Han were randomly selected from our previous randomized cluster samples [34,35]. All of them come from both Lihu and Baxu villages in Nandan County, Guangxi Zhuang Autonomous Region, People's Republic of China. They were undergone routine physical examination and appropriate laboratory tests. Ages of the Bai $\mathrm{Ku}$ Yao subjects ranged from 15 to 80 years, the average age was $39.74 \pm 16.01$ years old. There were 324 males (47.86\%) and 353 females (52.14\%). The mean age of the Han subjects was $41.29 \pm 16.39$ years (range 15 to 80 ). There were 315 men (48.76\%) and 331 women (51.24\%). Both the Han and Bai Ku Yao subjects had no evidence of any chronic illness, including hepatic, renal, or thyroid. The participants with a history of heart attack or myocardial infarction, stroke, congestive heart failure, diabetes or fasting blood glucose $\geq 7.0 \mathrm{mmol} / \mathrm{L}$ determined by glucose meter were also excluded. The participants were not taking medications known to affect serum lipid levels (lipid-lowering drugs such as statins 
or fibrates, beta-blockers, diuretics, or hormones). The present study was approved by the Ethics Committee of the First Affiliated Hospital, Guangxi Medical University. Informed consent was obtained from all participants.

\section{Epidemiological survey}

The epidemiological survey was carried out under internationally standardized methods by following a general protocol [36]. Common information on demographics, socioeconomic status, and lifestyle factors of the participants was collected by answering all the detailed questions of a standardized questionnaire. The data of alcohol consumption included questions about the number of liangs (about $50 \mathrm{~g}$ ) of rice wine, corn wine, rum, beer, or liquor consumed during the preceding 12 months. Alcohol consumption was categorized into groups of grams of alcohol per day: $<25$ and $\geq 25$. Smoking status was divided into groups of cigarettes per day: $<20$ and $\geq 20$. Several parameters such as height, weight, and waist circumference were measured. Sitting blood pressure was measured three times with the use of a mercury sphygmomanometer after a 5-min rest, and the average of the three measurements was used for the level of blood pressure. Systolic blood pressure was determined by the first Korotkoff sound, and diastolic blood pressure by the fifth Korotkoff sound. Body weight, to the nearest 50 grams, was measured using a portable balance scale. Subjects were weighed without shoes and in a minimum of clothing. Height was measured, to the nearest $0.5 \mathrm{~cm}$, using a portable steel measuring device. From these two measurements body mass index (BMI, $\mathrm{kg} / \mathrm{m}^{2}$ ) was calculated.

\section{Biochemical analyses}

Venous blood sample $(8 \mathrm{~mL})$ was obtained from each subject between 8 and 11 AM, after 12 hours of fasting. A part of the sample $(3 \mathrm{~mL})$ was collected into glass tube and used to determine serum lipid levels. The remaining of the sample $(5 \mathrm{~mL})$ was transferred to tubes with anticoagulate solution $(4.80 \mathrm{~g} / \mathrm{L}$ citric acid, $14.70 \mathrm{~g} /$ $\mathrm{L}$ glucose, and $13.20 \mathrm{~g} / \mathrm{L}$ tri-sodium citrate) and used to extract DNA. The levels of serum total cholesterol (TC), triglyceride (TG), HDL-C, and LDL-C in samples were detected by enzymatic methods with commercially available kits, Tcho-1, TG-LH (RANDOX Laboratories Ltd., Ardmore, Diamond Road, Crumlin Co. Antrim, United Kingdom, BT29 4QY), Cholestest N HDL, and Cholestest LDL (Daiichi Pure Chemicals Co., Ltd., Tokyo, Japan), respectively. Serum ApoAI and ApoB levels were detected by the immunoturbidimetric immunoassay using a commercial kit (RANDOX Laboratories Ltd.). All determinations were performed with an autoanalyzer (Type 7170A; Hitachi Ltd., Tokyo, Japan) in the Clinical
Science Experiment Center of the First Affiliated Hospital, Guangxi Medical University.

\section{DNA amplification and genetic analysis}

Genomic DNA from peripheral blood leukocytes was extracted using the phenol-chloroform method [37-42]. To detect the genetypes, a polymerase chain reaction and restriction fragment length polymorphism (PCRRFLP) assay was developed [29]. Each $25 \mu \mathrm{L}$ PCR amplication mixture contained 5-200 ng DNA, $10 \times$ PCR buffer $\left(1.8 \mathrm{mM} \mathrm{MgCl}_{2}\right) 2.5 \mu \mathrm{L}, 1 \mathrm{U}$ Taq polymerase, 2.5 $\mathrm{mmol} / \mathrm{L}$ of each dNTP (Tiangen, Beijing, People's Republic of China) $2.0 \mu \mathrm{L}, 5 \mathrm{pmol} / \mathrm{L}$ of each primer $(0.5 \mu \mathrm{L})$. The paired primer sequences were: forward, 5'-GGTAGCCCACCACTCCCCTAAAG-3'; reverse, 5'-ATCAGCTGCCTGTCCTTGGACTA-3' (Sangon, Shanghai, People's Republic of China). The PCR amplification reaction was under a cycling protocol of processing started with $95^{\circ} \mathrm{C}$ for $5 \mathrm{~min}$; and 30 cycles at $94^{\circ} \mathrm{C}$ for $30 \mathrm{~s}, 58^{\circ} \mathrm{C}$ for $45 \mathrm{~s}$ and $72^{\circ} \mathrm{C}$ for $30 \mathrm{~s}$ and a final extension at $72^{\circ} \mathrm{C}$ for $5 \mathrm{~min}$ were followed. RFLP assay was performed using $10 \mathrm{U}$ of the appropriate restriction enzyme TagI per $10 \mu \mathrm{L}$ PCR products and incubated at $65^{\circ} \mathrm{C}$ for $1-16$ hours as the manufacture described. The genotypes were identified by electrophoresis on $2 \%$ agarose gels and visualized with ethidium-bromide staining, ultraviolet illumination. Genotypes were scored by an experienced reader blinded to epidemiological data and serum lipid levels. Six samples (GG, GA and AA genotypes in two; respectively) detected by the PCR-RFLP were also confirmed by sequencing directly. The PCR products were purified by low melting point gel electrophoresis and phenol extraction, and then the DNA sequences were analyzed in Shanghai Sangon Biological Engineering Technology \& Services Co., Ltd., People's Republic of China.

\section{Diagnostic criteria}

The normal values of serum TC, TG, HDL-C, LDL-C, ApoAI and ApoB levels, and the ratio of ApoAI to ApoB in our Clinical Science Experiment Center were 3.10-5.17, 0.56-1.70, 0.91-1.81, 2.70-3.20 mmol/L, 1.00$1.78,0.63-1.14 \mathrm{~g} / \mathrm{L}$, and $1.00-2.50$; respectively. The individuals with $\mathrm{TC}>5.17 \mathrm{mmol} / \mathrm{L}$ and/or $\mathrm{TG}>1.70 \mathrm{mmol} /$ $\mathrm{L}$ were defined as hyperlipidemic [34,35]. Hypertension was diagnosed according to the criteria of 1999 World Health Organization-International Society of Hypertension Guidelines for the management of hypertension $[43,44]$. The diagnostic criteria of overweight and obesity were according to the Cooperative Meta-analysis Group of China Obesity Task Force. Normal weight, overweight and obesity were defined as a BMI <24, 24-28, and $>28 \mathrm{~kg} / \mathrm{m}^{2}$; respectively [45]. 
Table 1 The general characteristics and serum lipid levels between the Bai Ku Yao and Han populations

\begin{tabular}{|c|c|c|c|c|}
\hline Parameter & Bai Ku Yao & Han Chinese & $t\left(\chi^{2}\right)$ & $P$ \\
\hline Number & 677 & 646 & - & - \\
\hline Male/female & $324 / 353$ & $315 / 331$ & 0.108 & 0.783 \\
\hline Age (years) & $39.74 \pm 16.01$ & $41.29 \pm 16.39$ & -1.734 & 0.083 \\
\hline Body mass index $\left(\mathrm{kg} / \mathrm{m}^{2}\right)$ & $22.08 \pm 2.39$ & $22.40 \pm 3.15$ & -2.082 & 0.038 \\
\hline Systolic blood pressure $(\mathrm{mmHg})$ & $118.6 \pm 17.01$ & $121.70 \pm 16.72$ & -3.294 & 0.001 \\
\hline Diastolic blood pressure $(\mathrm{mmHg})$ & $75.18 \pm 9.64$ & $76.27 \pm 10.86$ & -1.936 & 0.053 \\
\hline Pulse pressure $(\mathrm{mmHg})$ & $43.46 \pm 12.69$ & $45.44 \pm 10.97$ & -3.026 & 0.003 \\
\hline \multicolumn{5}{|l|}{ Cigarette smoking [n (\%)] } \\
\hline Nonsmoker & $477(70.5)$ & $458(70.5)$ & & \\
\hline$<20$ cigarettes/day & $93(13.0)$ & $84(13.7)$ & & \\
\hline$\geq 20$ cigarettes/day & $107(16.1)$ & $104(15.8)$ & 0.160 & 0.923 \\
\hline \multicolumn{5}{|l|}{ Alcohol consumption [n (\%)] } \\
\hline Nondrinker & $386(57.0)$ & $406(62.8)$ & & \\
\hline$<25$ g/day & $219(32.3)$ & $105(16.3)$ & & \\
\hline$\geq 25 \mathrm{~g} /$ day & $72(10.6)$ & $135(20.9)$ & 59.096 & 0.000 \\
\hline Total cholesterol (mmol/L) & $4.31 \pm 0.91$ & $4.71 \pm 1.01$ & -7.485 & 0.000 \\
\hline Triglycerides (mmol/L) & $1.00(0.65)$ & $1.01(0.64)$ & -1.1670 & 0.243 \\
\hline $\mathrm{HDL}-\mathrm{C}(\mathrm{mmol} / \mathrm{L})$ & $1.65 \pm 0.40$ & $1.88 \pm 0.49$ & -9.271 & 0.000 \\
\hline LDL-C (mmol/L) & $2.55 \pm 0.75$ & $2.62 \pm 0.76$ & -1.663 & 0.097 \\
\hline Apolipoprotein (Apo) Al (g/L) & $1.29 \pm 0.31$ & $1.41 \pm 0.28$ & -7.067 & 0.000 \\
\hline ApoB (g/L) & $0.84 \pm 0.22$ & $0.89 \pm 0.23$ & -4.134 & 0.000 \\
\hline ApoAl/ApoB & $1.65 \pm 0.70$ & $1.68 \pm 0.57$ & -4.484 & 0.628 \\
\hline
\end{tabular}

HDL-C, high-density lipoprotein cholesterol; LDL-C, low-density lipoprotein cholesterol. The value of TG was presented as median (interquartile range). The difference between the two ethnic groups was determined by the Wilcoxon-Mann-Whitney test.

\section{Statistical analyses}

Epidemiological data were recorded on a pre-designed form and managed with Excel software. All statistical analyses were done with the statistical software package SPSS 17.0 (SPSS Inc., Chicago, Illinois). Quantitative variables were expressed as mean \pm standard deviation (serum TG levels were presented as medians and interquartile ranges). Qualitative variables were expressed as percentages. Allele frequency was determined via direct counting, and the standard goodness-of-fit test was used to test the Hardy-Weinberg equilibrium. Difference in genotype distribution between the groups was obtained using the chi-square test. The difference in general characteristics between Bai $\mathrm{Ku}$ Yao and Han was tested by the Student's unpaired $t$-test. The association of genotypes and serum lipid parameters was tested by analysis of covariance (ANCOVA). Sex, age, BMI, blood pressure, alcohol consumption, cigarette smoking were adjusted for the statistical analysis. Multivariate linear regression analysis with stepwise modeling was performed to evaluate the association of serum lipid levels with genotypes (GG $=1, \mathrm{GA}=2$ and $\mathrm{AA}=3$ ) and several environment factors in the combined population of Bai Ku Yao and Han, Bai Ku Yao, Han, males, and females; respectively. A $P$ value of less than 0.05 was considered statistically significant.

\section{Results}

General characteristics and serum lipid levels

The general characteristics and serum lipid levels between the Bai $\mathrm{Ku}$ Yao and Han populations are summarised in Table 1. The levels of height, weight, BMI, systolic blood pressure, pulse pressure, serum TC, HDL$\mathrm{C}$, ApoAI and ApoB were lower in Bai $\mathrm{Ku}$ Yao than in Han $(P<0.05-0.001)$, whereas the percentages of subjects who consumed alcohol were higher in Bai Ku Yao than in Han $(P<0.001)$. There were no significant differences in the levels of diastolic blood pressure, serum TG, LDL-C, the ratio of ApoAI to ApoB, age structure, the percentage of subjects who smoked cigarettes, or the ratio of male to female between the two ethnic groups $(P>0.05$ for all).

\section{Electrophoresis and genotypes}

After the genomic DNA of the samples was amplified by PCR and imaged by $2 \%$ agarose gel electrophoresis, the purpose gene of 525 bp nucleotide sequences could be found in all samples (Figure 1). The genotypes identified were named according to the presence or absence of the enzyme restriction sites, when a $\mathrm{G}$ to $\mathrm{A}$ transversion at 825 locus of the ABCA1 gene. The presence of the cutting site indicates the A allele, while its absence indicates the $\mathrm{G}$ allele (cannot be cut). Thus, the GG genotype is 


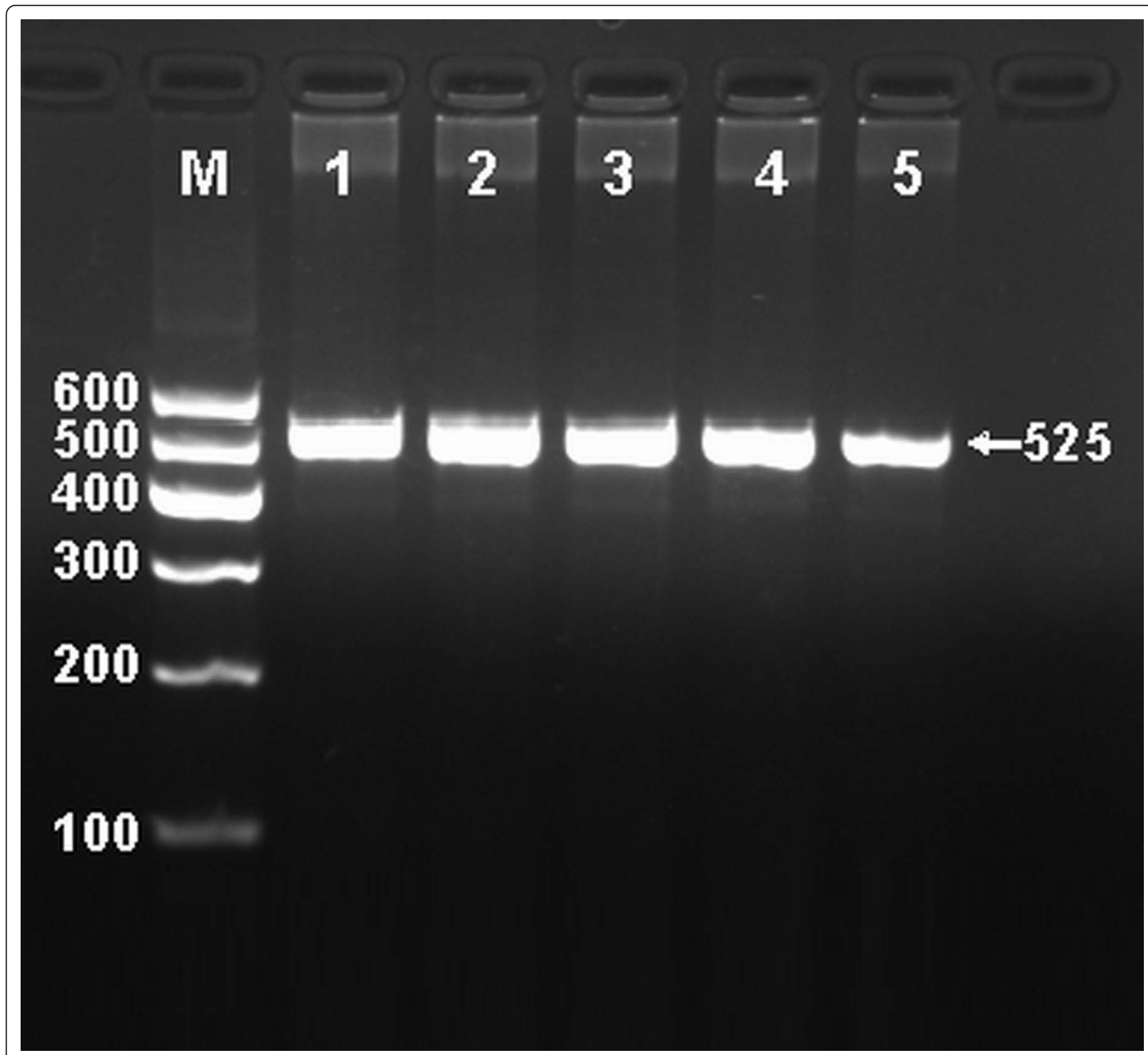

Figure 1 Electrophoresis of PCR products of the samples. Lane M, 100 bp marker ladder; lanes 1-5, samples. The 525 bp bands are the target genes.

homozygote for the absence of the site (band at $525 \mathrm{bp}$ ), GA genotype is heterozygote for the absence and presence of the site (bands at 525-, 302- and 223-bp), and AA genotype is homozygote for the presence of the site (bands at 302- and 223-bp; Figure 2).

\section{Genotypic and allelic frequencies}

Table 2 gives the genotypic and allelic frequencies of V825I polymorphism in the ABCA1 gene. The frequency of $\mathrm{G}$ and $\mathrm{A}$ alleles was $57.4 \%$ and $42.6 \%$ in Bai $\mathrm{Ku} \mathrm{Yao}$, and $57.7 \%$ and $42.3 \%$ in Han $(P>0.05)$; respectively. The frequency of GG, GA and AA genotypes was $33.7 \%, 47.4 \%$ and $18.9 \%$ in Bai Ku Yao, and 33.4\%,
$48.6 \%$ and $18.0 \%$ in $\operatorname{Han}(P>0.05)$; respectively. There was no significant difference in the genotypic and allelic frequencies between males and females in both ethnic groups.

\section{The nucleotide sequence of V825I polymorphism}

The results were shown as GG, GA and AA genotypes by PCR-RFLP, the GG, GA and AA genotypes were also confirmed by sequencing (Figure 3); respectively.

\section{Genotypes and serum lipid levels}

As shown in Table 3, the levels of TC in Bai Ku Yao but not in Han was different among the GG, GA and AA 


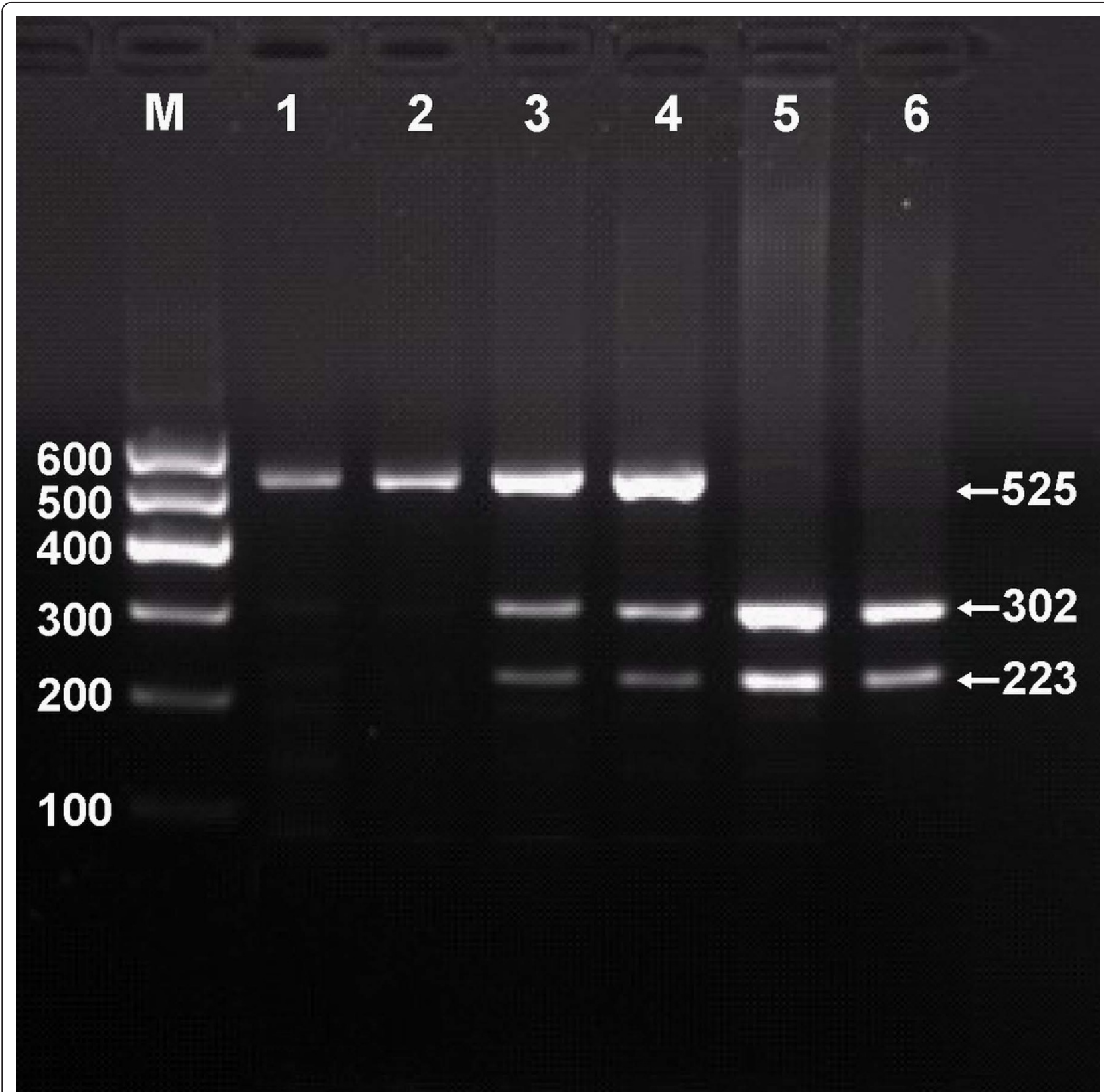

Figure 2 Genotyping of V825I polymorphism in the ABCA1 gene. Lane M, 100 bp marker ladder; lanes 1 and 2, GG genotype (525 bp); lanes 3 and 4, GA genotype (525-, 302- and 223-bp); and lanes 5 and 6, AA genotype (302- and 223-bp).

genotypes $(P<0.05)$, the subjects with AA genotype had higher serum TC levels than the subjects with GG and GA genotypes.

The levels of HDL-C and ApoAI in Han but not in Bai Ku Yao was different among the GG, GA and AA genotypes $(P<0.05)$, the subjects with AA genotype had lower serum HDL-C and ApoAI levels than the subjects with GG and GA genotypes, but these findings were restricted to males but not females.

\section{Relative factors for serum lipid parameters}

Multivariate linear regression analysis showed that the levels of TC in Bai Ku Yao and HDL-C and ApoAI in Han were correlated with genotypes $(P<0.05$ for all; Table 4). When the multivariate linear regression analysis was performed according to sex in both ethnic groups; respectively, we found that the levels of HDL-C and ApoAI in Han were correlated with genotypes in males but not in females $(P<0.05$ for each, Table 5$)$. 
Table 2 Genotypic and allelic frequencies of the ABCA1 V825I polymorphism between the Bai Ku Yao and Han populations [n (\%)]

\begin{tabular}{|c|c|c|c|c|c|c|}
\hline \multirow[t]{2}{*}{ Group } & \multirow[t]{2}{*}{$n$} & \multicolumn{3}{|c|}{ Genotype } & \multicolumn{2}{|c|}{ Allele } \\
\hline & & GG & GA & AA & G & A \\
\hline Bai Ku Yao & 677 & $\begin{array}{c}228 \\
(33.7)\end{array}$ & $\begin{array}{c}321 \\
(47.4)\end{array}$ & $\begin{array}{c}128 \\
(18.9)\end{array}$ & $\begin{array}{c}777 \\
(57.4)\end{array}$ & $\begin{array}{c}577 \\
(42.6)\end{array}$ \\
\hline $\begin{array}{l}\text { Han } \\
\text { Chinese }\end{array}$ & 646 & $\begin{array}{c}216 \\
(33.4)\end{array}$ & $\begin{array}{c}314 \\
(48.6)\end{array}$ & $\begin{array}{c}116 \\
(18.0)\end{array}$ & $\begin{array}{c}746 \\
(57.7)\end{array}$ & $\begin{array}{c}546 \\
(42.3)\end{array}$ \\
\hline$\chi^{2}$ & - & & 0.265 & & & \\
\hline$P$ & - & & 0.876 & & & \\
\hline \multicolumn{7}{|l|}{ Bai Ku Yao } \\
\hline Male & 324 & $\begin{array}{c}110 \\
(34.0)\end{array}$ & $\begin{array}{c}153 \\
(47.2)\end{array}$ & $61(18.8)$ & $\begin{array}{c}373 \\
(57.6)\end{array}$ & $\begin{array}{c}275 \\
(42.4)\end{array}$ \\
\hline Female & 353 & $\begin{array}{c}118 \\
(33.4)\end{array}$ & $\begin{array}{c}168 \\
(47.6)\end{array}$ & $67(19.0)$ & $\begin{array}{c}404 \\
(57.2)\end{array}$ & $\begin{array}{c}302 \\
(42.8)\end{array}$ \\
\hline$\chi^{2}$ & - & & 0.210 & & & \\
\hline P & - & & 0.990 & & & \\
\hline \multicolumn{7}{|l|}{$\begin{array}{c}\text { Han } \\
\text { Chinese }\end{array}$} \\
\hline Male & 315 & $\begin{array}{c}104 \\
(33.0)\end{array}$ & $\begin{array}{c}154 \\
(48.9)\end{array}$ & $57(18.1)$ & $\begin{array}{c}362 \\
(57.5)\end{array}$ & $\begin{array}{c}268 \\
(42.5)\end{array}$ \\
\hline Female & 331 & $\begin{array}{c}112 \\
(33.8)\end{array}$ & $\begin{array}{c}160 \\
(48.3)\end{array}$ & $59(17.8)$ & $\begin{array}{c}384 \\
(58.0)\end{array}$ & $\begin{array}{c}278 \\
(42.0)\end{array}$ \\
\hline$\chi^{2}$ & - & & 0.490 & & & \\
\hline$P$ & - & & 0.976 & & & \\
\hline
\end{tabular}

Serum lipid parameters were also correlated with sex, age, BMI, alcohol consumption, cigarette smoking, and blood pressure in both ethnic groups (Tables 4 and 5).

\section{Discussion}

In the present study, we reported the serum lipid profiles in two Chinese populations, Bai Ku Yao and Han. It offered evidence again to confirm that the levels of serum TC, HDL-C, ApoAI and ApoB were lower in Bai $\mathrm{Ku}$ Yao than in Han. The findings were also emphasized in a previous study [34]. There was no significant difference in the levels of serum TG, LDL-C and the ratio of ApoAI to ApoB between the two ethnic groups. It has been confirmed that dyslipidemia is a condition caused by multifactors, including hereditary and modifiabled risk factors. Bai Ku Yao is an isolated subgroup of the Yao minority in China. They reside in two villages, Lihu and Baxu, Nandan County. Both villages are typical infertile mountain area. The main agricultural crops are corn and paddy. Strict intra-ethnic marriages and special diet have been performed in this population from time immemorial. Therefore, the hereditary characteristics and genotypes of some lipid metabolism-related genes in this population may be different from those in Han Chinese.
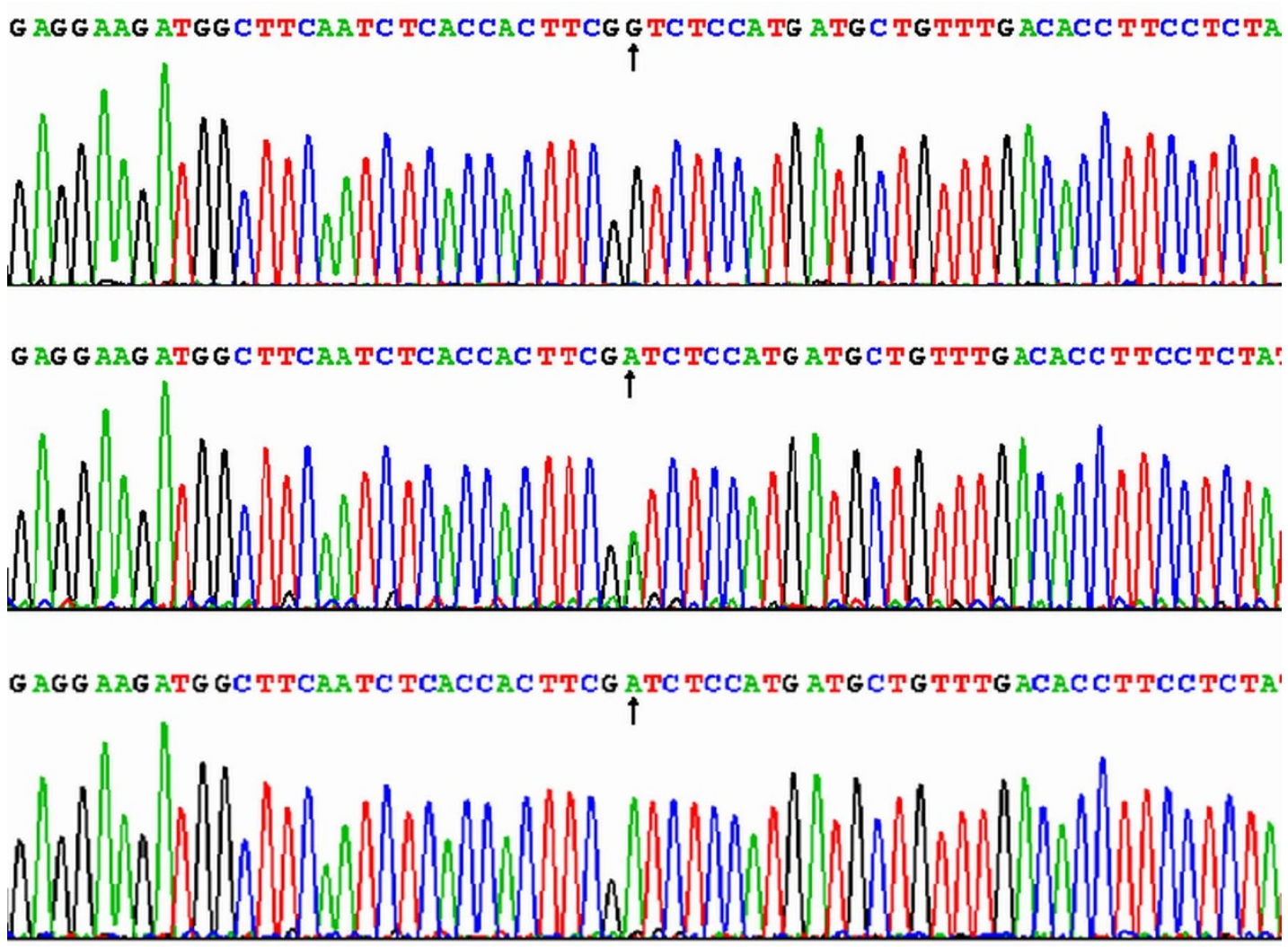

Figure 3 A part of the nucleotide sequence of the ABCA1 V825I polymorphism. (A) GG genotype; (B) GA genotype; (C) AA genotype. 
Table 3 Genotypic frequencies of the ABCA1 V825I polymorphism and serum lipid levels between the Bai Ku Yao and Han populations

\begin{tabular}{|c|c|c|c|c|c|c|c|c|}
\hline Genotype & $\mathbf{n}$ & $\mathrm{TC}(\mathrm{mmol} / \mathrm{L})$ & TG $(\mathrm{mmol} / \mathrm{L})$ & $\mathrm{HDL}-\mathrm{C}(\mathrm{mmol} / \mathrm{L})$ & LDL-C (mmol/L) & ApoAl (g/L) & ApoB (g/L) & ApoAl/ApoB \\
\hline \multicolumn{9}{|l|}{ Bai Ku Yao } \\
\hline GG & 228 & $4.28 \pm 0.79$ & $1.09(0.80)$ & $1.63 \pm 0.39$ & $2.52 \pm 0.65$ & $1.30 \pm 0.34$ & $0.84 \pm 0.21$ & $1.65 \pm 0.69$ \\
\hline GA & 321 & $4.26 \pm 0.82$ & $0.96(0.61)$ & $1.64 \pm 0.41$ & $2.52 \pm 0.68$ & $1.28 \pm 0.29$ & $0.83 \pm 0.22$ & $1.64 \pm 0.63$ \\
\hline $\mathrm{AA}$ & 128 & $4.52 \pm 1.26$ & $0.95(0.61)$ & $1.72 \pm 0.45$ & $2.69 \pm 1.04$ & $1.33 \pm 0.35$ & $0.86 \pm 0.26$ & $1.73 \pm 0.91$ \\
\hline$F$ & - & 3.839 & 4.621 & 2.073 & 2.358 & 1.460 & 0.663 & 0.862 \\
\hline P & - & 0.022 & 0.099 & 0.127 & 0.095 & 0.233 & 0.516 & 0.423 \\
\hline \multicolumn{9}{|l|}{ Male } \\
\hline GG & 110 & $4.29 \pm 0.80$ & $1.25(0.91)$ & $1.65 \pm 045$ & $2.43 \pm 0.68$ & $1.36 \pm 0.39$ & $0.82 \pm 0.21$ & $1.81 \pm 0.86$ \\
\hline GA & 153 & $4.26 \pm 0.88$ & $1.00(0.66)$ & $1.67 \pm 0.45$ & $2.47 \pm 0.73$ & $1.32 \pm 0.33$ & $081 \pm 021$ & $1.76 \pm 0.74$ \\
\hline $\mathrm{AA}$ & 61 & $4.53 \pm 1.62$ & $1.02(0.68)$ & $1.74 \pm 0.56$ & $2.63 \pm 1.33$ & $1.40 \pm 0.44$ & $0.83 \pm 0.30$ & $1.96 \pm 1.19$ \\
\hline$F$ & - & 1.850 & 4.969 & 0.974 & 1.377 & 1.040 & 0.081 & 1.370 \\
\hline$P$ & - & 0.159 & 0.083 & 0.379 & 0.254 & 0.355 & 0.922 & 0.256 \\
\hline \multicolumn{9}{|l|}{ Female } \\
\hline GG & 118 & $4.26 \pm 0.80$ & $0.97(0.62)$ & $1.60 \pm 0.33$ & $2.59 \pm 0.62$ & $1.25 \pm 0.26$ & $0.87 \pm 0.20$ & $1.50 \pm 0.44$ \\
\hline GA & 168 & $4.26 \pm 0.77$ & $0.94(0.56)$ & $1.62 \pm 0.36$ & $2.57 \pm 0.63$ & $1.24 \pm 0.25$ & $0.85 \pm 0.22$ & $1.53 \pm 0.47$ \\
\hline $\mathrm{AA}$ & 67 & $4.50 \pm 0.80$ & $0.92(0.49)$ & $1.69 \pm 0.31$ & $2.73 \pm 0.68$ & $1.27 \pm 0.22$ & $0.89 \pm 0.20$ & $1.51 \pm 0.45$ \\
\hline$F$ & - & 2.860 & 0.595 & 1.530 & 2.080 & 0.474 & 1.150 & 0.578 \\
\hline P & - & 0.059 & 0.743 & 0.220 & 0.126 & 0.623 & 0.320 & 0.560 \\
\hline \multicolumn{9}{|l|}{ Han Chinese } \\
\hline GG & 216 & $4.77 \pm 0.99$ & $1.00(0.57)$ & $1.92 \pm 0.51$ & $2.61 \pm 0.72$ & $1.43 \pm 0.27$ & $0.89 \pm 0.22$ & $1.70 \pm 0.58$ \\
\hline GA & 314 & $4.71 \pm 1.06$ & $1.01(0.68)$ & $1.90 \pm 0.48$ & $2.62 \pm 0.81$ & $1.42 \pm 0.28$ & $0.89 \pm 0.24$ & $1.69 \pm 0.57$ \\
\hline $\mathrm{AA}$ & 116 & $4.63 \pm 0.90$ & $1.02(0.70)$ & $1.78 \pm 0.48$ & $2.64 \pm 0.67$ & $1.36 \pm 0.27$ & $0.90 \pm 0.21$ & $1.58 \pm 0.51$ \\
\hline$F$ & - & 0.600 & 0.682 & 3.797 & 0.190 & 3.650 & 0.220 & 1.930 \\
\hline P & - & 0.540 & 0.711 & 0.023 & 0.674 & 0.027 & 0.800 & 0.145 \\
\hline \multicolumn{9}{|l|}{ Male } \\
\hline GG & 104 & $4.77 \pm 1.03$ & $1.01(0.59)$ & $1.89 \pm 0.55$ & $2.62 \pm 0.73$ & $1.42 \pm 0.30$ & $0.90 \pm 0.23$ & $1.69 \pm 0.68$ \\
\hline GA & 154 & $4.59 \pm 1.13$ & $1.01(0.64)$ & $1.80 \pm 0.49$ & $2.56 \pm 0.86$ & $1.36 \pm 0.29$ & $0.87 \pm 0.25$ & $1.68 \pm 0.61$ \\
\hline $\mathrm{AA}$ & 57 & $4.50 \pm 1.04$ & $1.03(0.78)$ & $1.71 \pm 0.49$ & $2.58 \pm 0.72$ & $1.32 \pm 0.30$ & $0.88 \pm 0.22$ & $1.61 \pm 0.59$ \\
\hline$F$ & - & 1.039 & 0.062 & 3.590 & 0.037 & 3.020 & 0.102 & 0.575 \\
\hline P & - & 0.355 & 0.970 & 0.029 & 0.964 & 0.049 & 0.903 & 0.564 \\
\hline \multicolumn{9}{|l|}{ Female } \\
\hline GG & 112 & $4.72 \pm 0.96$ & $0.96(0.56)$ & $1.94 \pm 0.47$ & $2.59 \pm 0.71$ & $1.43 \pm 0.24$ & $0.89 \pm 0.21$ & $1.70 \pm 0.48$ \\
\hline GA & 160 & $4.83 \pm 0.97$ & $1.02(0.77)$ & $1.99 \pm 0.45$ & $2.68 \pm 0.75$ & $1.43 \pm 0.26$ & $0.91 \pm 0.22$ & $1.72 \pm 0.53$ \\
\hline $\mathrm{AA}$ & 59 & $4.76 \pm 0.75$ & $0.99(0.58)$ & $1.85 \pm 0.47$ & $2.70 \pm 0.63$ & $1.39 \pm 0.23$ & $0.93 \pm 0.20$ & $1.55 \pm 0.42$ \\
\hline F & - & 0.390 & 1.182 & 2.150 & 0.538 & 2.640 & 0.760 & 2.133 \\
\hline P & - & 0.677 & 0.554 & 0.118 & 0.585 & 0.073 & 0.469 & 0.120 \\
\hline
\end{tabular}

TC, total cholesterol; TG, triglyceride; HDL-C, high-density lipoprotein cholesterol; LDL-C, low-density lipoprotein cholesterol; ApoAl, apolipoprotein Al; ApoB, apolipoprotein $\mathrm{B}$; ApoAI/ApoB, the ratio of apolipoprotein Al to apolipoprotein $\mathrm{B}$. The value of TG was presented as median (interquartile range). The difference among the genotypes was determined by the Kruskal-Wallis test.

We showed that the frequency of A allele in Bai $\mathrm{Ku}$ Yao (42.6\%) was similar to that in Han Chinese (42.3\%). There was also no significant difference in the genotypic and allelic frequencies between males and females in the both ethnic groups. However, the frequency of A allele in our study populations was higher than that in a previous report from the Han Chinese [29]. Li et al. [29] reported that the frequency of A allele was $32.3 \%$ in 386 Han healthy individuals, and the frequency of GG, GA and AA genetypes was $44.9 \%, 45.5 \%$ and $9.6 \%$; respectively. Tan et al. [31] showed that the frequency of A allele in male healthy controls in the Singapore Chinese, Malays and Indians was 41.7\%, 24.9\% and 5.5\%; respectively. In a total of 515 Chinese, 112 Malay, 166 Indian male CHD patients, the frequency of A allele was $44.6 \%$, $31.8 \%$ and $8.4 \%$; respectively. However, the frequency of A allele in European was very low. It was 6\% in Danish general population, $5 \%$ in low and $8 \%$ in high HDL-C subjects [26,28], 5.6\% in participants from Belfast (Northern Ireland) and 6\% in those from Glasgow (Scotland) [46], and $8.1 \%$ in Dutch [30]. These results indicate that the prevalence of the A allele variation of 
Table 4 Correlative factors for serum lipid parameters between the Bai Ku Yao and Han populations

\begin{tabular}{|c|c|c|c|c|c|}
\hline Lipid parameter & Relative factor & Standardized coefficient & Standard error & $t$ & $P$ \\
\hline \multicolumn{6}{|l|}{ Bai plus Han } \\
\hline \multirow[t]{6}{*}{$\mathrm{TC}$} & Body mass index & 0.100 & 0.150 & 2.318 & 0.021 \\
\hline & Age & 0.194 & 0.002 & 7.234 & 0.000 \\
\hline & Ethnic group & -1.159 & 0.050 & -6.200 & 0.001 \\
\hline & Diastolic blood pressure & 0.094 & 0.003 & 3.400 & 0.001 \\
\hline & Weight & 0.164 & 0.006 & 0.164 & 0.000 \\
\hline & Sex & 0.087 & 0.061 & 0.087 & 0.005 \\
\hline \multirow[t]{2}{*}{ TG } & Weight & 0.216 & 0.004 & 7.889 & 0.000 \\
\hline & Alcohol consumption & 0.114 & 0.042 & 4.168 & 0.000 \\
\hline \multirow[t]{5}{*}{$\mathrm{HDL}-\mathrm{C}$} & Age & 0.211 & 0.001 & 8.214 & 0.000 \\
\hline & Ethnic group & -0.235 & 0.023 & -9.336 & 0.000 \\
\hline & Alcohol consumption & 0.233 & 0.018 & 8.246 & 0.000 \\
\hline & Sex & 0.127 & 0.026 & 4.541 & 0.000 \\
\hline & Body mass index & -0.069 & 0.004 & -2.689 & 0.007 \\
\hline \multirow[t]{5}{*}{ LDL-C } & Body mass index & 0.093 & 0.012 & 2.097 & 0.036 \\
\hline & Age & 0.188 & 0.001 & 6.975 & 0.000 \\
\hline & Alcohol consumption & -0.090 & 0.029 & -3.092 & 0.002 \\
\hline & Weight & 0.209 & 0.004 & 4.412 & 0.000 \\
\hline & Sex & 0.084 & 0.051 & 2.491 & 0.013 \\
\hline \multirow[t]{5}{*}{ ApoAl } & Age & 0.221 & 0.001 & 8.308 & 0.000 \\
\hline & Alcohol consumption & 0.230 & 0.012 & 8.126 & 0.000 \\
\hline & Ethnic group & -0.171 & 0.015 & -6.759 & 0.000 \\
\hline & Diastolic blood pressure & 0.061 & 0.001 & 2.272 & 0.023 \\
\hline & Sex & 0.057 & 0.017 & 2.021 & 0.044 \\
\hline \multirow[t]{5}{*}{ ApoB } & Body mass index & 0.237 & 0.002 & 8.922 & 0.000 \\
\hline & Age & 0.160 & 0.000 & 5.999 & 0.000 \\
\hline & Ethnic group & -0.087 & 0.012 & -3.393 & 0.001 \\
\hline & Diastolic blood pressure & 0.105 & 0.001 & 3.784 & 0.000 \\
\hline & Sex & 0.081 & 0.012 & 3.098 & 0.002 \\
\hline \multirow[t]{2}{*}{ ApoAl/ApoB } & Alcohol consumption & 0.165 & 0.023 & 6.103 & 0.000 \\
\hline & Body mass index & -0.155 & 0.006 & -5.722 & 0.000 \\
\hline \multicolumn{6}{|l|}{ Bai Ku Yao } \\
\hline \multirow[t]{3}{*}{$\mathrm{TC}$} & Body mass index & 0.216 & 0.014 & 5.821 & 0.000 \\
\hline & Age & 0.139 & 0.002 & 3.730 & 0.000 \\
\hline & Genotype & 0.076 & 0.048 & 2.051 & 0.041 \\
\hline \multirow[t]{4}{*}{ TG } & Alcohol consumption & 0.197 & 0.068 & 4.194 & 0.000 \\
\hline & Body mass index & 0.133 & 0.016 & 3.505 & 0.000 \\
\hline & Sex & -0.154 & 0.099 & -3.099 & 0.002 \\
\hline & Smoking & -0.125 & 0.066 & -2.485 & 0.013 \\
\hline \multirow[t]{2}{*}{$\mathrm{HDL}-\mathrm{C}$} & Alcohol consumption & 0.204 & 0.022 & 5.502 & 0.000 \\
\hline & Age & 0.177 & 0.001 & 4.765 & 0.000 \\
\hline \multirow[t]{3}{*}{ LDL-C } & Body mass index & 0.219 & 0.012 & 5.812 & 0.000 \\
\hline & Age & 0.114 & 0.002 & 3.034 & 0.003 \\
\hline & Alcohol consumption & -0.080 & 0.042 & -2.107 & 0.035 \\
\hline \multirow[t]{2}{*}{ ApoAl } & Alcohol consumption & 0.310 & 0.017 & 8.602 & 0.000 \\
\hline & Age & 0.167 & 0.001 & 4.639 & 0.000 \\
\hline \multirow[t]{2}{*}{ ApoB } & Alcohol consumption & 0.287 & 0.039 & 7.748 & 0.000 \\
\hline & Body mass index & -0.153 & 0.011 & -4.138 & 0.000 \\
\hline \multirow[t]{3}{*}{ ApoAl/ApoB } & Body mass index & 0.207 & 0.004 & 5.463 & 0.000 \\
\hline & Age & 0.102 & 0.001 & 2.674 & 0.008 \\
\hline & Sex & 0.106 & 0.017 & 2.800 & 0.005 \\
\hline
\end{tabular}


Table 4 Correlative factors for serum lipid parameters between the Bai Ku Yao and Han populations (Continued)

\begin{tabular}{|c|c|c|c|c|c|}
\hline & Diastolic blood pressure & 0.094 & 0.001 & 2.365 & 0.018 \\
\hline \multicolumn{6}{|l|}{ Han Chinese } \\
\hline \multirow[t]{4}{*}{ TC } & Age & 0.254 & 0.002 & 6.807 & 0.000 \\
\hline & Diastolic blood pressure & 0.128 & 0.004 & 3.264 & 0.001 \\
\hline & Weight & 0.281 & 0.004 & 7.109 & 0.000 \\
\hline & Sex & 0.165 & 0.076 & 4.387 & 0.000 \\
\hline \multirow[t]{2}{*}{ TG } & Weight & 0.278 & 0.005 & 7.293 & 0.000 \\
\hline & Alcohol consumption & 0.078 & 0.060 & 2.033 & 0.043 \\
\hline \multirow[t]{5}{*}{$\mathrm{HDL}-\mathrm{C}$} & Age & 0.260 & 0.001 & 7.014 & 0.000 \\
\hline & Alcohol consumption & 0.218 & 0.023 & 5.628 & 0.000 \\
\hline & Sex & 0.151 & 0.039 & 3.770 & 0.000 \\
\hline & Weight & -0.100 & 0.002 & -2.606 & 0.009 \\
\hline & Genotype & -0.088 & 0.025 & -2.444 & 0.015 \\
\hline \multirow[t]{3}{*}{ LDL-C } & Age & 0.249 & 0.002 & 6.620 & 0.000 \\
\hline & Weight & 0.196 & 0.005 & 3.524 & 0.000 \\
\hline & Alcohol consumption & -0.124 & 0.035 & -3.299 & 0.001 \\
\hline \multirow[t]{5}{*}{ ApoAl } & Age & 0.307 & 0.001 & 8.091 & 0.000 \\
\hline & Alcohol consumption & 0.170 & 0.013 & 4.441 & 0.000 \\
\hline & Sex & 0.169 & 0.021 & 4.464 & 0.000 \\
\hline & Diastolic blood pressure & 0.085 & 0.001 & 2.231 & 0.026 \\
\hline & Genotype & -0.071 & 0.014 & -1.988 & 0.047 \\
\hline \multirow[t]{3}{*}{ ApoB } & Body mass index & 0.261 & 0.003 & 6.957 & 0.000 \\
\hline & Age & 0.228 & 0.001 & 6.086 & 0.000 \\
\hline & Diastolic blood pressure & 0.106 & 0.001 & 2.732 & 0.006 \\
\hline ApoAl/ApoB & Body mass index & -0.167 & 0.007 & -4.305 & 0.000 \\
\hline
\end{tabular}

TC, total cholesterol; TG, triglyceride; HDL-C, high-density lipoprotein cholesterol; LDL-C, low-density lipoprotein cholesterol; ApoAl, apolipoprotein Al; ApoB, apolipoprotein B.

V825I in the ABCA1 gene may have an ethnic specificity.

The present study also demonstrated that there was a significant association between the $\mathrm{A}$ allele and increased serum TC levels in the Bai $\mathrm{Ku}$ Yao population and decreased serum HDL-C and ApoAI levels in the male Han population. Conversely, several previous studies found that the V825I polymorphism in the ABCA1 gene was associated with increased serum HDL-C levels [26-29]. Frikke-Schmidt et al. [26,28] showed that the A allele carriers had an increased tendency of HDL-C levels in female individuals from the Danish general population but not in males. They thought that the lack of significant association in men for V825I was partly due to less-significant effects on HDL-C in men. Kyriakou et al. [27] found that the 825I/825I homozygotes in European ancestry CHD patients had higher mean HDL-C levels than $825 \mathrm{~V} / 825 \mathrm{I}$ heterozygotes who in turn had higher mean HDL-C levels than $825 \mathrm{~V} / 825 \mathrm{~V}$ homozygotes. The relationships were still observed after adjusting for age, gender, smoking, BMI, hypertension, type 1 diabetes, type 2 diabetes and family history of CHD $(P=0.048)$. In addition, age of symptom onset in $825 \mathrm{I} / 825 \mathrm{I}$ homozygotes was 2.71 years higher than that in $825 \mathrm{~V} / 825 \mathrm{I}$ heterozygotes and 3.76 years higher than that in $825 \mathrm{~V} / 825 \mathrm{~V}$ homozygotes. Li et al. [29] found that the V825I polymorphism may affect ApoAI levels in Han Chinese population, but the influence depended on the haplotype generated from V825I and R1587K. The IK carriers had lower serum ApoAI levels than the VR carriers. In the current study, the association of V825I polymorphism and serum ApoAI levels, to some extent at least, was in agreement with a previous study in Han Chinese [29], but the influence on decreased serum HDL-C level in Han Chinese was reverse to that from Danish general population and European ancestry population [26-29]. However, several previous reports failed to find a significant association between the V825I polymorphism in the ABCA1 gene and serum HDL-C levels [30-33]. Clee et al. [30] showed that there was no significant difference in the plasma HDL-C levels between the A carriers and noncarriers in CHD patients in a Dutch cohort prospective study, but increased CHD events was observed in the trial $(P=0.0008)$. Tan et al. [31] reported that no obviously changes in serum lipid levels were observed in G or A allele carriers in Singapore CHD and CHD-free males (Chinese, Malays and Indian), but the V825I polymorphism clearly associated 
Table 5 Correlative factors for serum lipid parameters between males and females in both ethnic groups

\begin{tabular}{|c|c|c|c|c|c|}
\hline Lipid parameter & Relative factor & Standardized coefficient & Standard error & $t$ & $P$ \\
\hline \multicolumn{6}{|l|}{ Bai Ku Yao } \\
\hline \multicolumn{6}{|l|}{ Male } \\
\hline \multirow[t]{2}{*}{$\mathrm{TC}$} & Body mass index & 0.268 & 0.023 & 5.036 & 0.000 \\
\hline & Age & 0.130 & 0.007 & 2.434 & 0.015 \\
\hline TG & Body mass index & 0.216 & 0.031 & 3.973 & 0.000 \\
\hline \multirow[t]{3}{*}{$\mathrm{HDL}-\mathrm{C}$} & Alcohol consumption & 0.229 & 0.037 & 5.033 & 0.000 \\
\hline & Age & 0.275 & 0.002 & 4.286 & 0.000 \\
\hline & Body mass index & -0.116 & 0.011 & -0.201 & 0.028 \\
\hline LDL-C & Body mass index & 0.261 & 0.021 & 4.854 & 0.000 \\
\hline \multirow[t]{2}{*}{ ApoAl } & Alcohol consumption & 0.313 & 0.028 & 5.887 & 0.000 \\
\hline & Age & 0.187 & 0.001 & 3.519 & 0.000 \\
\hline ApoB & Body mass index & 0.293 & 0.006 & 5.496 & 0.000 \\
\hline \multirow[t]{2}{*}{ ApoAl/ApoB } & Alcohol consumption & 0.272 & 0.068 & 4.983 & 0.000 \\
\hline & Body mass index & -0.188 & 0.022 & -3.449 & 0.001 \\
\hline \multicolumn{6}{|l|}{ Female } \\
\hline \multirow[t]{2}{*}{$\mathrm{TC}$} & Body mass index & 0.170 & 0.016 & 3.253 & 0.001 \\
\hline & Age & 0.148 & 0.003 & 2.824 & 0.005 \\
\hline TG & Alcohol consumption & 0.205 & 0.080 & 3.919 & 0.000 \\
\hline \multirow[t]{2}{*}{ LDL-C } & Body mass index & 0.168 & 0.013 & 3.209 & 0.001 \\
\hline & Age & 0.162 & 0.002 & 3.012 & 0.002 \\
\hline \multirow[t]{2}{*}{ ApoAl } & Age & 0.159 & 0.001 & 2.300 & 0.003 \\
\hline & Body mass index & 0.160 & 0.001 & 2.030 & 0.022 \\
\hline \multirow[t]{3}{*}{ ApoB } & Systolic blood pressure & 0.328 & 0.008 & 3.067 & 0.002 \\
\hline & Body mass index & 0.202 & 0.003 & 3.321 & 0.001 \\
\hline & Weight & 0.025 & 0.117 & 2.053 & 0.041 \\
\hline ApoAl/ApoB & Diastolic blood pressure & -0.155 & 0.003 & -2.937 & 0.004 \\
\hline \multicolumn{6}{|l|}{ Han Chinese } \\
\hline \multicolumn{6}{|l|}{ Male } \\
\hline \multirow[t]{3}{*}{$\mathrm{TC}$} & Weight & 0.334 & 0.006 & 6.638 & 0.000 \\
\hline & Age & 0.228 & 0.003 & 4.424 & 0.000 \\
\hline & Alcohol consumption & 0.152 & 0.065 & 2.932 & 0.004 \\
\hline $\mathrm{TG}$ & Weight & 0.385 & 0.009 & 7.379 & 0.000 \\
\hline \multirow[t]{4}{*}{$\mathrm{HDL}-\mathrm{C}$} & Age & 0.336 & 0.002 & 6.729 & 0.000 \\
\hline & Alcohol consumption & 0.309 & 0.031 & 6.148 & 0.000 \\
\hline & Weight & -0.016 & 0.003 & -3.278 & 0.007 \\
\hline & Genotype & -0.131 & 0.035 & -2.711 & 0.000 \\
\hline \multirow[t]{2}{*}{ LDL-C } & Weight & 0.287 & 0.004 & 5.389 & 0.000 \\
\hline & Age & 0.174 & 0.007 & 3.273 & 0.001 \\
\hline \multirow[t]{3}{*}{ ApoAl } & Age & 0.377 & 0.001 & 7.609 & 0.000 \\
\hline & Alcohol consumption & 0.278 & 0.017 & 5.622 & 0.000 \\
\hline & Genotype & -0.125 & 0.020 & -2.599 & 0.010 \\
\hline \multirow[t]{4}{*}{ ApoB } & Body mass index & 0.295 & 0.004 & 5.718 & 0.000 \\
\hline & Age & 0.208 & 0.001 & 3.930 & 0.000 \\
\hline & Smoking & 0.124 & 0.014 & 2.422 & 0.016 \\
\hline & Alcohol consumption & 0.106 & 0.015 & 2.005 & 0.046 \\
\hline \multirow[t]{2}{*}{ ApoAl/ApoB } & Age & 0.118 & 0.020 & 2.100 & 0.037 \\
\hline & Body mass index & -0.172 & 0.011 & -3.054 & 0.002 \\
\hline \multicolumn{6}{|l|}{ Female } \\
\hline $\mathrm{TC}$ & Age & 0.278 & 0.007 & 5.317 & 0.000 \\
\hline & Weight & 0.210 & 0.006 & 4.075 & 0.000 \\
\hline & Diastolic blood pressure & 0.152 & 0.005 & 2.855 & 0.005 \\
\hline
\end{tabular}


Table 5 Correlative factors for serum lipid parameters between males and females in both ethnic groups (Continued)

\begin{tabular}{llllll}
\hline TG & Diastolic blood pressure & 0.167 & 0.005 & 3.072 & 0.002 \\
HDL-C & Age & 0.198 & 0.002 & 3.658 & 0.000 \\
LDL-C & Weight & 0.317 & 0.005 & 6.462 & 0.000 \\
& Age & 0.327 & 0.002 & 6.597 & 0.000 \\
& Alcohol consumption & -0.167 & 0.052 & -3.375 & 0.001 \\
ApoAl & Age & 0.286 & 0.001 & 5.433 & 0.000 \\
& Weight & 0.117 & 0.002 & 2.220 & 0.027 \\
& Body mass index & 0.251 & 0.004 & 4.878 & 0.000 \\
& Age & 0.240 & 0.001 & 4.625 & 0.000 \\
& Diastolic blood pressure & 0.124 & 0.001 & 2.344 & 0.020 \\
\hline
\end{tabular}

TC, total cholesterol; TG, triglyceride; HDL-C, high-density lipoprotein cholesterol; LDL-C, low-density lipoprotein cholesterol; ApoAl, apolipoprotein Al; ApoB, apolipoprotein B.

with CHD status in male Malays. The reason for these conflicting results is not fully understood, probably because of differences in study designs, sample size, race, the methods used to determine serum lipid levels and the polymorphism, as well as gene-enviromental interactions. To our knowledge, the association of the V825I polymorphism and serum TC levels has not been described previously. Thus, further studies are needed to clarify.

Our study also revealed that environmental factors play an important role in serum lipid regulation in the two populations [34]. Multivariate linear regression analysis showed that sex, age, BMI, blood pressure, alcohol consumption, and cigarette smoking were involved in determining serum lipid parameters. The difference in serum lipid profiles between Bai $\mathrm{Ku}$ Yao and Han might partly result from different food items and life style factors. The staple food in Bai Ku Yao was corn and the subsidiary foods were rice, soy, buckwheat, sweet potato, and pumpkin products. Approximately $90 \%$ of the beverages were corn wine and rum. The alcohol content is about 15\% (v/ v). They are also accustomed to drink hempseed soup and eat hempseed products. In contrast, the staple food in Han was rice and the subsidiary foods were corn, broomcorn, potato, and taro products. About $90 \%$ of the beverage was rice wine. The content of alcohol is about $30 \%(\mathrm{v} / \mathrm{v})$. A number of experimental and clinical studies have demonstrated that the staple and subsidiary foods and the beverages were more beneficial for serum lipid profiles in Bai Ku Yao than in Han [47-57].

\section{Conclusion}

The present study shows that there is no difference in the genotypic and allelic frequencies between the Han and Bai Ku Yao populations, or between males and females in the both ethnic groups. But the V825I polymorphism in the ABCA1 gene is found to be associated with male serum HDL-C and ApoAI levels in the Han, and serum TC levels in the Bai Ku Yao populations. The participants with AA genotype in Han male had lower serum HDL-C and ApoAI levels than the participants with GG and GA genotypes, whereas the subjects with AA genotype in Bai $\mathrm{Ku}$ Yao had higher serum TC levels than the subjects with GG and GA genotypes. The difference in the association of V825I polymorphism and serum lipid levels between the two ethnic groups might partly result from different ABCA1 geneenviromental interactions.

\section{Acknowledgements}

This study was supported by the National Natural Science Foundation of China (No: 30660061).

\section{Author details}

${ }^{1}$ Department of Cardiology, Institute of Cardiovascular Diseases, the First Affiliated Hospital, Guangxi Medical University, 22 Shuangyong Road, Nanning 530021, Guangxi, People's Republic of China. ${ }^{2}$ Department of Neurology, the First Affiliated Hospital, Guangxi Medical University, 22 Shuangyong Road, Nanning 530021, Guangxi, People's Republic of China. ${ }^{3}$ Department of Molecular Biology, Medical Scientific Research Center, Guangxi Medical University, 22 Shuangyong Road, Nanning 530021, Guangxi, People's Republic of China. ${ }^{4}$ Department of Pathophysiology, School of Premedical Sciences, Guangxi Medical University, Nanning 530021, Guangxi, People's Republic of China.

\section{Authors' contributions}

$\mathrm{XLC}$ participated in the design, undertook genotyping, and drafted the manuscript. RXY conceived the study, participated in the design, carried out the epidemiological survey, collected the samples, and helped to draft the manuscript. DFW, LM, LHHA, XJH, QL and TTY collaborated to the genotyping. WXL and SLP carried out the epidemiological survey, collected the samples, and helped to carry out the genotyping. All authors read and approved the final manuscript.

\section{Competing interests}

The authors declare that they have no competing interests.

Received: 4 January 2011 Accepted: 19 January 2011

Published: 19 January 2011

\section{References}

1. Singaraja RR, Brunham LR, Visscher H, Kastelein JJ, Hayden MR: Efflux and atherosclerosis: the clinical and biochemical impact of variations in the ABCA1 gene. Arterioscler Thromb Vasc Biol 2003, 23:1322-32. 
2. Miller GJ, Miller NE: Plasma-high-density-lipoprotein concentration and development of ischaemic heart-disease. Lancet 1975, 1:16-9.

3. Wilson PW, Abbott RD, Castelli WP: High density lipoprotein cholesterol and mortality. The Framingham Heart Study. Arteriosclerosis 1988, 8:737-41.

4. Garcia CK, Wilund K, Arca M, Zuliani G, Fellin R, Maioli M, Calandra S, Bertolini S, Cossu F, Grishin N, Barnes R, Cohen JC, Hobbs HH: Autosomal recessive hypercholesterolemia caused by mutations in a putative LDL receptor adaptor protein. Science 2001, 292:1394-8.

5. Goldbourt U, Yaari S, Medalie JH: Isolated low HDL cholesterol as a risk factor for coronary heart disease mortality. A 21-year follow-up of 8000 men. Arterioscler Thromb Vasc Biol 1997, 17:107-13.

6. Glomset JA: The plasma lecithin:cholesterol acyltransferase reaction. J Lipid Res 1968, 9:155-67.

7. Fielding CJ, Fielding PE: Molecular physiology of reverse cholesterol transport. J Lipid Res 1995, 36:211-28.

8. Steinmetz J, Boerwinkle E, Gueguen R, Visvikis S, Henny J, Siest G: Multivariate genetic analysis of high density lipoprotein particles. Atherosclerosis 1992, 92:219-27.

9. Heller DA, de Faire U, Pedersen NL, Dahlén G, McClearn GE: Genetic and environmental influences on serum lipid levels in twins. $N$ Engl I Med 1993, 328:1150-6.

10. Pérusse L, Rice T, Després JP, Bergeron J, Province MA, Gagnon J, Leon AS, Rao DC, Skinner JS, Wilmore JH, Bouchard C: Familial resemblance of plasma lipids, lipoproteins and postheparin lipoprotein and hepatic lipases in the HERITAGE Family Study. Arterioscler Thromb Vasc Biol 1997. 17:3263-9.

11. Cuchel M, Rader DJ: Genetics of increased HDL cholesterol levels. Insights into the relationship between HDL metabolism and atherosclerosis. Arterioscler Thromb Vasc Biol 2004, 23:1710-2.

12. Jones PM, George AM: Mechanism of ABC transporters: a molecular dynamics simulation of a well characterized nucleotide-binding subunit. Proc Natl Acad Sci USA 2002, 99:12639-44.

13. Kwiterovich PO Jr: The metabolic pathways of high-density lipoprotein, low-density lipoprotein, and triglycerides: a current review. Am J Cardiol 2000, 86:5L-10L.

14. Oram JF: Tangier disease and ABCA1. Biochim Biophys Acta 2000, 1529:321-30.

15. Remaley AT, Rust S, Rosier M, Knapper C, Naudin L, Broccardo C, Peterson KM, Koch C, Arnould I, Prades C, Duverger N, Funke H, Assman G, Dinger M, Dean M, Chimini G, Santamarina-Fojo S, Fredrickson DS, Denefle P, Brewer HB Jr: Human ATP-binding cassette transporter 1 (ABC1): genomic organization and identification of the genetic defect in the original Tangier disease kindred. Proc Natl Acad Sci USA 1999, 96:12685-90.

16. Brooks-Wilson A, Marcil M, Clee SM, Zhang LH, Roomp K, van Dam M, Yu L, Brewer C, Collins JA, Molhuizen HO, Loubser O, Ouelette BF, Fichter K, Ashbourne-Excoffon KJ, Sensen CW, Scherer S, Mott S, Denis M, Martindale D, Frohlich J, Morgan K, Koop B, Pimstone S, Kastelein JJ, Genest J Jr, Hayden MR: Mutations in ABC1 in Tangier disease and familial high-density lipoprotein deficiency. Nat Genet 1999, 22:336-45.

17. Bodzioch M, Orsó E, Klucken J, Langmann T, Böttcher A, Diederich W, Drobnik W, Barlage S, Büchler C, Porsch-Ozcürümez M, Kaminski WE, Hahmann HW, Oette K, Rothe G, Aslanidis C, Lackner KJ, Schmitz G: The gene encoding ATP-binding cassette transporter 1 is mutated in Tangier disease. Nat Genet 1999, 22:347-51.

18. Rust S, Rosier M, Funke H, Real J, Amoura Z, Piette JC, Deleuze JF, Brewer HB, Duverger N, Denèfle P, Assmann G: Tangier disease is caused by mutations in the gene encoding ATP-binding cassette transporter 1 . Nat Genet 1999, 22:352-5.

19. Modzioch M, Orso E, Klucken J, Langmann T, Bottcher A, Diederich W, Drobnik W, Barlage S, Buchler C, PorschOzcurumez M, Kaminski WE, Hahmann HW, Oette K, Rothe G, Aslanidis C, Lackner KJ, Schmitz G: The gene encoding ATP-binding cassette transporter 1 is mutated in Tangier disease. Nat Genet 1999, 22:347-51.

20. Serfaty-Lacrosniere C, Civeira F, Lanzberg A, Isaia P, Berg J, Janus ED, Smith MP Jr, Pritchard PH, Frohlich J, Lees RS: Homozygous Tangier disease and cardiovascular disease. Atherosclerosis 1994, 107:85-98

21. Clee SM, Kastelein JJ, van Dam M, Marcil M, Roomp K, Zwarts KY, Collins JA, Roelants R, Tamasawa N, Stulc T, Suda T, Ceska R, Boucher B, Rondeau C, DeSouich C, Brooks-Wilson A, Molhuizen HO, Frohlich J, Genest J Jr, Hayden MR: Age and residual cholesterol efflux affect HDL cholesterol levels and coronary artery disease in ABCA1 heterozygotes. $J$ Clin Invest 2000, 106:1263-70.

22. van Dam MJ, de Groot E, Clee SM, Hovingh GK, Roelants R, BrooksWilson A, Zwinderman AH, Smit AJ, Smelt AH, Groen AK, Hayden MR, Kastelein JJ: Association between increased arterial-wall thickness and impairment in ABCA1-driven cholesterol efflux: an observational study. Lancet 2002, 359:37-42.

23. Schmitz G, Langmann T: Structure, function and regulation of the $A B C 1$ gene product. Curr Opin Lipidol 2001, 12:129-40.

24. Schmitz G, Kaminski WE, Orso E: ABC transporters in cellular lipid trafficking. Curr Opin Lipidol 2000, 11:493-501.

25. Dean M, Hamon Y, Chimini G: The human ATP-binding cassette (ABC) transporter superfamily. J Lipid Res 2001, 42:1007-17.

26. Frikke-Schmidt R, Nordestgaard BG, Jensen GB, Tybjaerg-Hansen A: Genetic variation in $A B C$ transporter $A 1$ contributes to $H D L$ cholesterol in the general population. J Clin Invest 2004, 114:1343-53.

27. Kyriakou T, Pontefract DE, Viturro E, Hodgkinson CP, Laxton RC, Bogari N, Cooper G, Davies M, Giblett J, Day IN, Simpson IA, Albrecht C, Ye S: Functional polymorphism in $A B C A 1$ influences age of symptom onset in coronary artery disease patients. Hum Mol Genet 2007, 16:1412-22.

28. Frikke-Schmidt R, Nordestgaard BG, Jensen GB, Steffensen R, TybjaergHansen A: Genetic variation in $A B C A 1$ predicts ischemic heart disease in the general population. Arterioscler Thromb Vasc Biol 2008, 28:180-6.

29. Li Y, Wang YM, Wang D, He Y: Relationship between polymorphisms in ABCA1 gene and plasma apolipoprotein A1 level. J Fourth Mil Med Univ 2008, 29:1018-20.

30. Clee SM, Zwinderman AH, Engert JC, Zwarts KY, Molhuizen HO, Roomp K, Jukema JW, van Wijland M, van Dam M, Hudson TJ, Brooks-Wilson A, Genest J Jr, Kastelein JJ, Hayden MR: Common genetic variation in ABCA1 is associated with altered lipoprotein levels and a modified risk for coronary artery disease. Circulation 2001, 103:1198-205.

31. Tan JH, Low PS, Tan YS, Tong MC, Saha N, Yang H, Heng CK: ABCA1 gene polymorphisms and their associations with coronary artery disease and plasma lipids in males from three ethnic populations in Singapore. Hum Genet 2003, 113:106-17.

32. Kakko S, Kelloniemi J, Kelloniemi J, von Rohr P, Hoeschele I, Tamminen M, Brousseau ME, Kesaniemi YA, Savolainen MJ: ATP-binding cassette transporter A1 locus is not a major determinant of HDL-C levels in a population at high risk for coronary heart disease. Atherosclerosis 2003, 166:285-90.

33. Mantaring M, Rhyne J, Ho Hong S, Miller M: Genotypic variation in ATPbinding cassette transporter-1 (ABCA1) as contributors to the high and low high-density lipoprotein-cholesterol (HDL-C) phenotype. Transl Res 2007, 149:205-10.

34. Ruixing Y, Qiming F, Dezhai Y, Shuquan L, Weixiong L, Shangling P, Hai W, Yongzhong $Y$, Feng $\mathrm{H}$, Shuming Q: Comparison of demography, diet, lifestyle, and serum lipid levels between the Guangxi Bai Ku Yao and Han populations. J Lipid Res 2007, 48:2673-81.

35. Ruixing $Y$, Jinzhen $W$, Yaoheng $H$, Jing $T$, Hai $W$, Muyan $L$, Yiyang $L$, Dongmei F, Hanjun Y, Yuming C: Associations of diet and lifestyle with hyperlipidemia for middle-aged and elderly persons among the Guangxi Bai Ku Yao and Han populations. J Am Diet Assoc 2008, 108:970-6.

36. People's Republic of China-United States Cardiovascular and Cardiopulmonary Epidemiology Research Group: An epidemiological study of cardiovascular and cardiopulmonary disease risk factors in four populations in the People's Republic of China. Baseline report from the P.R.C.-U.S.A. Collaborative Study. Circulation 1992, 85:1083-96.

37. Meng $L$, Ruixing $Y$, Yiyang $L$, Xingjiang $L$, Kela $L$, Wanying $L$, Lin $Z$, Weixiong L, Dezhai Y, Shangling P: Association of LIPC -250G > A polymorphism and several environmental factors with serum lipid levels in the Guangxi Bai Ku Yao and Han populations. Lipids Health Dis 2010, 9:28.

38. Ruixing $Y$, Yiyang $L$, Meng $L$, Kela $L$, Xingjiang $L$, Lin $Z$, Wanying $L$, Jinzhen W, Dezhai $Y$, Weixiong L: Interactions of the apolipoprotein C-III $3238 \mathrm{C}>\mathrm{G}$ polymorphism and alcohol consumption on serum triglyceride levels. Lipids Health Dis 2010, 9:86.

39. Liu WY, Yin RX, Zhang L, Cao XL, Miao L, Wu DF, Aung LH, Hu XJ, Lin WX, Yang DZ: Association of the LIPG 584C > T polymorphism and serum lipid levels in the Guangxi Bai Ku Yao and Han populations. Lipids Health Dis 2010, 9:110. 
40. Zhang L, Yin RX, Liu WY, Miao L, Wu DF, Aung LH, Hu XJ, Cao XL, Wu JZ, Pan SL: Association of methylenetetrahydrofolate reductase C677T polymorphism and serum lipid levels in the Guangxi Bai Ku Yao and Han populations. Lipids Health Dis 2010, 9:123.

41. Wu DF, Yin RX, Aung LH, Hu XJ, Cao XL, Miao L, Li Q, Yan TT, Wu JZ, Pan SL: Polymorphism of rs 10449925 in the acyl CoA:cholesterol acyltransferase-1 gene and serum lipid levels in the Guangxi Bai Ku Yao and Han populations. Lipids Health Dis 2010-139.

42. Miao L, Yin RX, Wu DF, Cao XL, Li Q, Hu XJ, Yan TT, Aung LH, Yang DZ, Lin WX: Peroxisome proliferator-activated receptor delta +294T >C polymorphism and serum lipid levels in the Guangxi Bai Ku Yao and Han populations. Lipids Health Dis 2010, 9:145.

43. Ruixing $Y$, Weixiong L, Hanjun $Y$, Dezhai $Y$, Shuquan L, Shangling $P$, Qiming F, Jinzhen W, Jianting G, Yaju D: Diet, lifestyle, and blood pressure of the middle-aged and elderly in the Guangxi Bai Ku Yao and Han populations. Am J Hypertens 2008, 21:382-7.

44. Ruixing Y, Shangling P, Shuquan L, Dezhai Y, Weixiong L, Qiming F, Yuming C, Yaoheng H, Yijiang Z, Qinchen L: Comparison of hypertension and its risk factors between the Guangxi Bai Ku Yao and Han populations. Blood Press 2008, 17:306-16.

45. Cooperative Meta-analysis Group of China Obesity Task Force: Predictive values of body mass index and waist circumference to risk factors of related diseases in Chinese adult population. Chin J Epidemiol 2002, 23:5-10.

46. Tregouet DA, Ricard S, Nicaud V, Arnould I, Soubigou S, Rosier M, Duverger $N$, Poirier $O$, Macé $S$, Kee F, Morrison C, Denèfle $P$, Tiret $L$, Evans A, Deleuze JF, Cambien F: In-depth haplotype analysis of ABCA1 gene polymorphisms in relation to plasma ApoA1 levels and myocardial infarction. Arterioscler Thromb Vasc Biol 2004, 24:775-81.

47. Dong W, Ma X, Zhang D, Yu S: Effect of maize embryo on delaying aging. Food Sci 2002, 23:95-7.

48. Shane JM, Walker PM: Corn bran supplementation of a low-fat controlled diet lowers serum lipids in men with hypercholesterolemia. J Am Diet Assoc 1995, 95:40-5.

49. Zhan S, Ho SC: Meta-analysis of the effects of soy protein containing isoflavones on the lipid profile. Am J Clin Nutr 2005, 81:397-408.

50. Tomotake H, Shimaoka I, Kayashita J, Yokoyama F, Nakajoh M, Kato N: Stronger suppression of plasma cholesterol and enhancement of the fecal excretion of steroids by a buckwheat protein product than by a soy protein isolate in rats fed on a cholesterol-free diet. Biosci Biotechnol Biochem 2001, 65:1412-4

51. Ludvik BH, Mahdjoobian K, WaldhaeusI W, Hofer A, Prager R, KautzkyWiller A, Pacini G: The effect of Ipomoea batatas (Caiapo) on glucose metabolism and serum cholesterol in patients with type 2 diabetes: a randomized study. Diabetes Care 2002, 25:239-40.

52. Adaramoye OA, Achem J, Akintayo OO, Fafunso MA: Hypolipidemic effect of Telfairia occidentalis (fluted pumpkin) in rats fed a cholesterol-rich diet. J Med Food 2007, 10:330-6.

53. Richard MN, Ganguly R, Steigerwald SN, Al-Khalifa A, Pierce GN: Dietary hempseed reduces platelet aggregation. J Thromb Haemost 2007, 5:424-5.

54. Cen L, Qin W, Ye Y: Effect of Canabis Sativa $L$ on serum cholesterol level in rats. J Guangxi Med Univ 1984, 1:20-2.

55. Schwab US, Callaway J, Erkkila AT, Gynther J, Uusitupa MI, Jarvinen T: Effects of hempseed and flaxseed oils on the profile of serum lipids, serum total and lipoprotein lipid concentrations and haemostatic factors. Eur J Nutr 2006, 45:470-7.

56. Ren HY, Sun HG, Ma JZ, Zhang Y, Yi CR, Wu MX, Liu WL, Li GL: Experimental study on the effects of hemp fruit oil on serun lipid levels and lipid peroxidation. Chin J Tradit Med Sci Technol 1997, 4:200.

57. Ren HY, Sun HG, Zhang Y, Yi CR, Wu MX, Li GL, Liu WL: Lipid-lowering and antiatherosclerotic effects of hemp fruit oil in partridges. Henan Tradit Chin Med 1998, 18:294-5.

\section{doi:10.1186/1476-511X-10-14}

Cite this article as: Cao et al: Genetic variant of V825I in the ATPbinding cassette transporter A1 gene and serum lipid levels in the Guangxi Bai Ku Yao and Han populations. Lipids in Health and Disease 2011 10:14.

\section{Submit your next manuscript to BioMed Central and take full advantage of:}

- Convenient online submission

- Thorough peer review

- No space constraints or color figure charges

- Immediate publication on acceptance

- Inclusion in PubMed, CAS, Scopus and Google Scholar

- Research which is freely available for redistribution 